\title{
The Investments in UAE by Foreign Investors in Real Estate for the Period 1970-2018 and its Repercussions on the Economy
}

Diaa Khalaf Ahmed Al Qatawneh ${ }^{1 *}$, Prof Ahmed Azrin Adnan ${ }^{2}$, Sameer A. A. AlZoughool ${ }^{3}$, Tamer Hussain Ahmed Alqudah $^{4}$

${ }^{1,3,4} \mathrm{Phd}$ Students, UniSZA University, Kuala Terengganu, Malaysia

${ }^{2}$ Lectrure, UniSZA University, Kuala Terengganu, Malaysia

DOI: $10.36347 /$ sjebm.2020.v07i01.006

| Received: 11.12.2019 | Accepted: 18.12.2019 | Published: 29.01.2020

*Corresponding author: Diaa Khalaf Ahmed Al Qatawneh

Abstract

Review Article

This research article provides information about the real estate industry of United Arab Emirates (UAE). It particularly focuses on the foreign investments that were made in the country from 1970 to 2018. The study is significantly important as UAE is one of the countries that is accessible to around two thirds of the population of the world within a flight of eight-hour and has Middle East, South Asia and Africa on its doorstep. Therefore, the country has unique location for facilitating international trade, particularly because of the advanced and top quality infrastructure. The foreign investment in country's real estate from 1970 onwards have increased significantly from every passing year and contribute significantly to the overll GDP of the country. The trend of foreign invesmtnet in the country in terms of real estate is expected to grow in the coming years, specifically in Dubai.

Keywords: Foreign Investors, Real Estate, Economy.

Copyright @ 2020: This is an open-access article distributed under the terms of the Creative Commons Attribution license which permits unrestricted use, distribution, and reproduction in any medium for non-commercial use (NonCommercial, or CC-BY-NC) provided the original author and source are credited.

\section{INTRODUCTION}

The United Arab Emirates or UAE is amongst the members of Gulf Cooperation Council (GCC). The GCC countries are Kuwait, Bahrain, Qatar, Oman, and the Kingdom of Saudi Arabia (KSA) and. UAE is also a member country of GCC OPEC along with Qatar, Kuwait and KSA. The economy of UAE is mostly dependable on a single resource, petroleum. The gross domestic income of UAE comes from one principal source i.e. by Petroleum which comprises of $85 \%$ of earnings [1]. FDI or the Foreign Direct Investment plays an important part for reducing the dependency on natural resources in order to diversify the country's economy in the long run. UAE's authorities intend to set up a knowledge-based sustainable economy, which is a part of UAE's 2021 sight. UAE's government stresses upon creating a diversified and sustianble economy, giving opportunities of home entrepreneurs to come forward and to look for ways in which they can attract more FDI [2]. Therefore, the FDI is anticipated as an important pillar in the transformation of any given economy.

The country has the right capability of attracting FDI, as reflected by potential index ranking of UNCTAD'. According to Masiur \& Khonaker [3], UAE ranked among $5^{\text {th }}$ among 142 economies which shows that it has a capability of becoming hub for global investment. It also encourages the authorities to achieve the dreams of expanding the economy.

\section{An Outline of UAE's Economy}

The economic crises are being faced by the world since generations and it is clearly slowing down the process of globalization worldwide. UAE is in competition and challenged by more strict global financial markets from other countries. One of the lessons learned from the recent economic crisis is that sustained economic growth depends on the better regulatory system and more capability to handle future crisis with diversified economy. Yet UAE has experienced some improvement in the last decade in its non-oil sector and also ranked $7^{\text {th }}$ in the Asian strongest economies [4]. During the years of economic crisis, the UAE economy performed fairly well. The UAE growth rate reached at high point back in 2006 and in 2007 it diminished then again GDP reached at high point and then low and it continued till 2011. After the crisis however the economy regained its confidence.

\section{Significance of the study}

The adequate of the construction sector and real estate and was the topic of concern for UAE's stakeholders. A Few years back, real estate and investors were receiving benefits from a a market wwhich was unregulated that led to high prices in the 
sector of real estate. Because of these factors, the prices were high. At last, in the end of 2007, the prices began to decrease. Despite of the fact thata the construction sector and real estate have improved in UAE, however, it still requires a lots of efforts in future to achieve a satisfactory point.

\section{Relevant Studies}

Significant attention from scholars is given to the sector of real estate in order to emphasis on the economy of UAE. Scherbina \& Nicholas [5] constructed price indexs for the real estate of United States in the years 1920- for comparing the value of property after arrival of the 1929's Great Depression. The data from over 7000 transactions was studied in Manhattan. This research is inspired by the study of Manhattan to analyze the overall real sector industry of UAE from 1970 to 2018 and its repercussion on the economy of UAE.

\section{FDI, Sources and Distributions}

According to the foreign trade of the country, the market of UAE is considered to be one of the most dynamic markets of the world. It comes amongst the sixteen largest exporters of the world. In 2000, the FDI stock grew 24\% of GDP and in 2011 the growth rate was at highest i.e. $49 \%$. A study found positive impact of country's FDI on the growth rate of industries in FDI host countries. It helped in increasing the capitalintensive as well as the development technological sectors [6].

The collection and circulation of Data related to FDI needs to be improvised in the countries of GCC. The FDI in India was higher as compared to UAE which was approximately $\$ 2.2$ billion USD from 2002 to 2009 [7]. Other studies in the past have identified the positive impact of FDI over the economic growth of countries. The authorities understand that the role of FDI is of key importance in improving a given economy in terms of sustainability and diversified portfolio. As per their vision of 2021 they plan to build a diversified and sustainable economy that gives opportunities and access to all of its residents and citizens. Developing such base encourages small and medium sized entrepreneurshippromotes the FDI in a country [8].

\section{Real Estate in the UAE}

The UAE's real estate sector has a strong history but some shocks and drops, yet remained an important pillar in the economy. Real estate in company with tourism and trade is one of the important sources of economic diversifications. The authorities have relatively understood that the oil sector bears remarkable risk in terms of volatility, therefore it was recommended to expand the UAE's economy to other sectors for a considerable time. As the key to achieving sustainable growth, the country's government started to encourage and impmrovise the real estate sector. In the mid 90 's only $3 \%$ of the total GDP is from real estate then with the efforts of government and country's growing attractiveness for businesspersons, the market started to get investments witnessing an unparalleled boom. Prices started to get increased by $20 \%-40 \%$ annually in between 2002-2005 and then in 2008 they faced a dramatic crash till 2009 just to rise again and to become a significant part of UAE's economy [9]. The real estate and construction sector witnessed signficiant growth from one year to another which contributed to around $15 \%$ of the country's GDP. Thus, unpredicted rise in these sectors made the authorities of Dubai and Abu Dhabi to acheeive the highest increase in the total number of projects. Abu Dhabi and Dubai became the hub for few of the leading companies of the world including EMAAR properties, PJSC, Nakheel, ALDAR, PJSC properties and others [10].

In order to gain sustainable growth, diversification still remains the most important factor in UAE and the authorities are firmly encouraging non-oil sectors to maintain their roles in the country's economy. Abu Dhabi, Sharjah and Dubai are recipient of this exceptional growth in real estate and construction projects. It was because of the property laws which have generated significant development in the sector of real estate. The development of free zoznes acted as catalsts of both foreign and local investors as they were being offered $100 \%$ ownership. They were also provided with single stop to complete all procedures and paperwork required. More profit was also expected due to the exemption of taxes and import duties. The macroeconomics factor of UAE were important in boasting the real estate sector in the country. The economic growth was high in the country along with strong liquidity position of the country. Over the eight years, the demand and prices of properties increased significant in UAE [11].

2008 marked as the year with the end of unequalled time of growth that was witnessed in the UAE as compared to the past years. The market of real estate started to slow down, number of jobs were also reduced and property prices began to go down and few projects were also stopped. In the last quarter of the year 2008, Dubai real estate's earning decreased significantly by an approximate USD 671 million amount [4]. According to Mina [12], the real estate transactions' index price was carried out in the UAE and it continued to show a downward trend in the last few months of 2008. The key challenges faced by the real estate as well as the construction sector at present are downfall of the prices, mortgage availability and a lack of trust in the market.

\section{Foreign Investment in UAE Real Estate}

In 2002, UAE's property market was opened to foreigners and the sector started to experience growth and expansion but in 2008, investors were quite afraid to invest in Dubai's market of real estate. It was mainly because the financial crisis affected many countries globally. But since the market bounced back things 
changed and now it's one of the world's strongest property markets which attract foreigners to invest in the projects due to great return on investment. UAE has proved over the last few years that it's the perfect overseas destination to offer affordable luxury investment opportunities with high return on investment and moreover providing with and outstanding infrastructure, variety for all budgets, security, growing economy and many more [11].

Most of the real estate and construction companies in UAE are public instead of private ones. According to Forbes these companies include Emaar properties which was established in 1977 and since then it's the local property giant in UAE. Another giant real estate company in Dubai, Al Nakheel Properties also known as Nakheel Corporation, has been rated to be among the popular and resource-endowed real estate companies in Dubai. The company mainly deals in freehold properties in the emirate and the company's real estate development ranges into tourist, residential, retail and commercial property. Next is DAMAC properties with profits of $\$ 1.2 \mathrm{bn}$, then comes ALDAR properties with $\$ 697$ million of profits. Other big projects are also in lined which Dubai land which will be the largest retail and entertainment world, with the size double of Walt Disney World Resort. Another one is Dubai Meydan City which includes racecourse hotels, sky bubble restaurants, clubs, plaza, towers and much more $[4,13]$.

\section{REPERCUSSIONS ON THE ECONOMY}

UAE's real estate sector is showing major improvements despite of the tough challenges affecting the entire region. A report has shown significant improvement in the value of real estate investments and transactions. Within this time period, the industry reached 106bn dirhams making a growth rate of $12 \%$. The study found that the real estate sector contributions to the GDP are almost doubled in 2018 as compared to 2017. Moreover, the construction sector witness record increases in GDP up to $6.4 \%$ from the previous year. According to the report, the real estate investment results indicate an increasing no of corporate investors compared to individual investors. This increment shows the ability of the market to provide investment options to attract investors and contribute the country's economy. On the other hand, they focus on providing transparent communication and openness to all investors and parties.

In 2017, individual investors made $62.8 \%$ of total investments and corporate investors jumped to $37.2 \%$. In 2018, real estate transactions worth $223 \mathrm{bn}$ dirhams were registered in the country. A significant increase in field investment is also shown which reached $80 \mathrm{bn}$ dirhams with 41,000 investments contributed by 31,000 investors around the world.

\section{CONCLUSION}

According to the study, the first five months of 2019 "witnessed the launch of 48 new real estate projects, which are expected to represent a new addition to the real estate sector." These projects include villas, residential apartments and villa complexes. Once they are completed it is expected that they turn around 8000 new residential spaces to the real estate sector. In 2018, the sales demand has increased taking up more than $63 \%$ of their total number. In terms of rents, Dubai's growing population and its ever-expanding expat base were reflected in the number of leased real estate units. UAE's Business Bay area ranked first in the number of real estate transactions and maintained the first position in transaction value with over 11 billion dirhams (\$29.9 billion).

\section{REFERENCES}

1. Shadab S. Tourism and economic growth in the United Arab Emirates: A Granger causality approach. Development. 2018.

2. Asif M. Growth and sustainability trends in the buildings sector in the GCC region with particular reference to the KSA and UAE. Renewable and Sustainable Energy Reviews.2016; 55, 1267-1273.

3. Masiur Rahman S, Khondaker AN, Imtiaz Hossain M, Shafiullah M and Hasan MA. Neurogenetic modeling of energy demand in the United Arab Emirates, Saudi Arabia, and Qatar. Environmental Progress \& Sustainable Energy.2017; 36(4), 1208-1216.

4. Kubursi AA. The Economies of the Arabian Gulf: A Statistical Source Book. Routledge; 2016.

5. Nicholas $\mathrm{T}$ and Scherbina A. Real estate prices during the roaring twenties and the great depression. Real Estate Economics.2013; 41(2), 278-309.

6. Cipollina A, Di Sparti MG, Tamburini A and Micale G. Development of a membrane distillation module for solar energy seawater desalination. Chemical engineering research and design,.2012; 90(12), 21012121.

7. Satyanand PN and Raghavendran P. Outward FDI from India and its policy context.2010.

8. Brugnoni GC, Di Lorenzo PGC, Didonato $\mathrm{R}$, Giustiniani E, Lentini L, Mariani $M$ and Tami A. Islamic Bonds and Real Estate Securitizations: The Italian Perspective for Issuing a Sukuk. In Empirical Studies on Economics of Innovation, Public Economics and Management. Springer, Cham;2017: 3-28

9. Al-Malkawi HAN and Pillai R. The impact of financial crisis on UAE real estate and construction sector: analysis and implications. Humanomics, 2013; 29(2), 115-135.

10. Sabnis GM. The effects of unskilled labor on the quality of concrete construction; 2010.

11. Diallo AK and Masih M. CO2 emissions and financial development: evidence from the United Arab Emirates based on an ARDL approach; 2017.

12. Mina W. United Arab Emirates FDI Outlook. The World Economy. 2014; 37(12), 1716-1730.

13. Cordesman AH. Bahrain, Oman, Qatar, and the UAE: Challenges of security. Routledge. 2018. 